\title{
Hepatic global DNA and peroxisome proliferator-activated receptor alpha promoter methylation are altered in peripartal dairy cows fed rumen-protected methionine
}

\author{
J. S. Osorio, ${ }^{*}$ C. B. Jacometo,† Z. Zhou, ${ }^{*}$ D. Luchini,ł F. C. Cardoso, ${ }^{*}$ and J. J. Loor*1 \\ *Mammalian NutriPhysioGenomics, Department of Animal Sciences and Division of Nutritional Sciences, University of Illinois, Urbana 61801 \\ †NUPEEC, Departamento de Clínicas Veterinária, Programa de Pós-Graduação em Biotecnologia, Universidade Federal de Pelotas, \\ 96010-900 Pelotas, RS, Brazil \\ $\ddagger$ Adisseo NA, Alpharetta, GA 30022
}

\section{ABSTRACT}

The availability of Met in metabolizable protein (MP) of a wide range of diets for dairy cows is low. During late pregnancy and early lactation, in particular, suboptimal Met in MP limits its use for mammary and liver metabolism and also for the synthesis of S-adenosylmethionine, which is essential for many biological processes, including DNA methylation. The latter is an epigenetic modification involved in the regulation of gene expression, hence, tissue function. Thirty-nine Holstein cows were fed throughout the peripartal period ( $-21 \mathrm{~d}$ to $30 \mathrm{~d}$ in milk) a basal control (CON) $\operatorname{diet}(\mathrm{n}=14)$ with no Met supplementation, CON plus MetaSmart (MS; Adisseo NA, Alpharetta, GA; n = 12), or CON plus Smartamine M (SM; Adisseo NA; $\mathrm{n}=$ 13). The total mixed ration dry matter for the close-up and lactation diets was measured weekly, then the Met supplements were adjusted daily and top-dressed over the total mixed ration at a rate of 0.19 (MS) or $0.07 \%$ (SM) on a dry matter basis. Liver tissue was collected on $-10,7$, and $21 \mathrm{~d}$ for global DNA and peroxisome proliferator-activated receptor alpha (PPAR $\alpha)$ promoter region-specific methylation. Several PPAR $\alpha$ target and putative target genes associated with carnitine synthesis and uptake, fatty acid metabolism, hepatokines, and carbohydrate metabolism were also studied. Data were analyzed using PROC MIXED of SAS (SAS Institute Inc., Cary, NC) with the preplanned contrast CON versus SM + MS. Global hepatic DNA methylation on d 21 postpartum was lower in Met-supplemented cows than CON. However, of 2 primers used encompassing 4 to 12 CpG sites in the promoter region of bovine PPARA, greater methylation occurred in the region encompassing $-1,538$ to $-1,418$ from the transcription start site

Received July 22, 2015.

Accepted September 17, 2015.

${ }^{1}$ Corresponding author: jloor@illinois.edu in cows supplemented with Met. Overall expression of PPARA was greater in Met-supplemented cows than CON. Concomitantly, PPARA-target genes, such as ANGPTL4, FGF21, and PCK1, were also upregulated overall by Met supplementation. The upregulation of PPAR $\alpha$ target genes indicates that supplemental Met, likely through the synthesis of S-adenosylmethionine, activated PPARA-regulated signaling pathways. Upregulation of hepatic PPARA has been associated with improved lipid metabolism and immune function, both of which were reported in companion publications from this study. In turn, those positive effects resulted in improved postpartal health and performance. Further research is needed to study more closely the mechanistic connections between global DNA and promoter regionspecific PPARA methylation with PPARA expression and functional outcomes in liver.

Key words: transition cow, metabolism, amino acids, methionine

\section{INTRODUCTION}

Among AA, the availability of Met in MP of a wide range of diets for dairy cows is low (NRC, 2001), hence, limiting its use for mammary and liver metabolism and also for the synthesis of the methylated compound S-adenosylmethionine (SAM; Martinov et al., 2010). Thus, it is not entirely surprising that supplementation of rumen-protected Met to lactating dairy cows confers beneficial effects on milk protein yield (Ordway et al., 2009), liver function, and antioxidant precursor synthesis (Osorio et al., 2014b).

Due to the multiple biological processes that require SAM, including transsulfuration, polyamine biosynthesis, and DNA methylation ( $\mathrm{Lu}$ and Mato, 2012), the requirement for methyl donors, such as choline and Met, increases at the onset of lactation (Preynat et al., 2009). The methylation of DNA regions is one of the epigenetic modifications involved in the regulation of gene expression. The epigenetic effect of SAM 
Table 1. Genes measured in liver tissue of cows fed a control diet or the control supplemented with MetaSmart (Adisseo NA) or Smartamine M (Adisseo NA) at a rate of 0.19 or $0.07 \%$ of DMI throughout the peripartal period

\begin{tabular}{|c|c|c|}
\hline Symbol & Description & Biological function \\
\hline TMLHE & Trimethyllysine hydroxylase, epsilon & $\begin{array}{l}\text { First enzyme in the carnitine biosynthesis } \\
\text { pathway }\end{array}$ \\
\hline$B B O X 1$ & $\gamma$-Butyrobetaine hydroxylase 1 & $\begin{array}{l}\text { Formation of L-carnitine from gamma- } \\
\text { butyrobetaine }\end{array}$ \\
\hline \multicolumn{3}{|c|}{ Fatty acid metabolism } \\
\hline$R X R A$ & Retinoid X receptor $\alpha$ & Transcription regulation \\
\hline$A C O X 1$ & Acyl-CoA oxidase 1 & $\begin{array}{l}\text { Rate-limiting enzyme of peroxisomal } \\
\beta \text {-oxidation }\end{array}$ \\
\hline$H M G C S 2$ & $\begin{array}{l}\text { 3-Hydroxy-3-methylglutaryl-Coenzyme A } \\
\text { synthase } 2\end{array}$ & Rate-limiting enzyme of ketogenesis \\
\hline CPT1A & Carnitine palmitoyltransferase $1 \mathrm{~A}$ & $\begin{array}{l}\text { Rate-limiting enzyme of mitochondrial } \\
\beta \text {-oxidation }\end{array}$ \\
\hline \multicolumn{3}{|c|}{ VLDL synthesis/export and gluconeogenesis } \\
\hline$P C$ & Pyruvate carboxylase & Gluconeogenesis \\
\hline MTTP & Microsomal triglyceride transfer protein & Essential for lipoprotein assembly \\
\hline $\mathrm{PDK}_{4}$ & Pyruvate dehydrogenase kinase, isozyme 4 & $\begin{array}{l}\text { Inhibits the pyruvate dehydrogenase } \\
\text { complex }\end{array}$ \\
\hline PCK1 & Phosphoenolpyruvate carboxykinase 1 & Gluconeogenesis \\
\hline$A P O B$ & Apolipoprotein B-100 & $\begin{array}{l}\text { Main apolipoprotein of very-low density } \\
\text { lipoproteins }\end{array}$ \\
\hline
\end{tabular}

through DNA methylation is partly driven by precursors of SAM, such as betaine and Met. In fact, such an epigenetic effect has been observed in rats fed betaine as a methyl donor with a consequent upregulation of the nuclear receptor peroxisome proliferator-activated receptor alpha (PPAR $\alpha$; gene symbol PPARA; Wang et al., 2013).

Peripartal dairy cows likely would benefit from activation of PPAR $\alpha$ via Met supplementation because its activation could trigger several adaptions such as reducing the inflammatory response, enhancing fatty acid oxidation, and preventing liver triacylglycerol (TAG) accumulation (Bionaz et al., 2013). Whether the same mechanism observed in rats can be extrapolated to dairy cows remains to be elucidated, especially during a stressful period such as the transition from pregnancy into lactation (i.e., the peripartal period).

Goselink et al. (2013) observed that rumen-protected choline reduced postpartal liver TAG and hypothesized that choline enhanced very low density lipoprotein (VLDL) synthesis, presumably by increasing the expression of apolipoprotein $\mathrm{B}(A P O B)$ and microsomal triglyceride transfer protein $(M T T P)$, both of which are PPAR $\alpha$ targets in nonruminants. Similar effects have been attributed to Met, which in nonruminants is a well-established lipotropic agent that can stimulate
VLDL synthesis and, consequently, minimizes the accumulation of TAG (Bauchart et al., 1998).

The objective of the present study was to use gene expression analysis coupled with global and promoter region-specific DNA methylation to evaluate the existence of additional mechanisms in liver associated with better postpartal performance and reduced peripartal inflammatory response with Met supplementation during the peripartal period (Osorio et al., 2013, 2014b). Liver tissue harvested during the peripartal period was used for transcriptome profiling of several PPAR $\alpha$ target and putative target genes (Table 1) associated with carnitine synthesis and uptake, fatty acid metabolism, hepatokines, and carbohydrate metabolism.

\section{MATERIALS AND METHODS}

\section{Animals and Experimental Design}

All procedures were conducted under protocols approved by the University of Illinois Institutional Animal Care and Use Committee. Details of the experimental design have been published previously (Osorio et al., 2013). Briefly, 45 Holstein cows entering their second or greater lactation were enrolled in the study and were fed experimental treatments consisting of a basal con- 
trol diet $(\mathbf{C O N} ; \mathrm{n}=14)$ with no Met supplementation, CON plus MetaSmart (MS; Adisseo NA, Alpharetta, $\mathrm{GA} ; \mathrm{n}=12)$ at a rate of $0.19 \%$ of $\mathrm{DM}$, and CON plus Smartamine M (SM; Adisseo NA; $\mathrm{n}=13)$ at a rate of $0.07 \%$ of DM (Osorio et al., 2013). All cows received a high-roughage diet (i.e., far-off diet; $1.24 \mathrm{Mcal} / \mathrm{kg}$ of $\mathrm{DM}, 14.3 \% \mathrm{CP})$ from -50 to $-21 \mathrm{~d}$ before expected calving, close-up diet (1.54 Mcal/kg of DM, 15\% CP) from $-21 \mathrm{~d}$ to expected calving, and a lactation diet from calving $(1.75 \mathrm{Mcal} / \mathrm{kg}$ of DM, $17.5 \% \mathrm{CP})$ through 30 DIM. Met supplements were top-dressed from -21 to 30 DIM. In addition, TMR DM for the close-up and lactation diets was measured weekly to estimate daily TMR DM offered. In turn, the amounts of MS $(0.19 \%)$ and SM $(0.07 \%)$ needed to reach our target level of Met supplementation were calculated using the data of TMR offered daily on a DM basis. A subset of cows $(\mathrm{CON}, \mathrm{n}=8$; MS, $\mathrm{n}=8$; SM, $\mathrm{n}=9$ ) from those mentioned above were used to evaluate hepatic transcriptomic profile. Animal husbandry for feeding system, sampling of ingredients, and TMR, BW, BCS, milk weights, sampling for milk composition, and housing of cows pre- and postpartum were as reported previously (Osorio et al., 2013).

\section{Liver Biopsy, RNA Extraction, Quantitative PCR, and Design and Evaluation of Primers}

Liver was sampled as previously described (Osorio et al., 2013) at approximately $0730 \mathrm{~h}$ on $-10,7$, and 21 $\mathrm{d}$ relative to parturition. Tissue specimens were stored in liquid $\mathrm{N}_{2}$ until RNA extraction. Total RNA was extracted from liver samples using establish protocols in our laboratory (see Supplemental Table S1 for details: http://dx.doi.org/10.3168/jds.2015-10157). Quantitative PCR, design, and primer evaluation were as reported previously (Osorio et al., 2014a). Genes were selected and evaluated based on key biological functions: carnitine synthesis and uptake, fatty acid metabolism, hepatokines, and carbohydrate metabolism (Table 1). Percentage relative abundance of mRNA (Supplemental Table S1) was calculated to provide additional mechanistic information on the target genes (Bionaz and Loor, 2008).

\section{DNA Extraction}

The DNA was isolated from $25 \mathrm{mg}$ of hepatic tissue using the Blood and Tissue DNeasy Kit (Qiagen, Hilden, Germany). Briefly, tissue was lysed using proteinase K, loaded to the DNeasy Mini spin column, DNA was selectively bound to the membrane, and contaminants were washed and finally eluted in water. To enhance samples quality, DNA was cleaned and concentrated using the Genomic DNA Clean and Concentrator (Zymo Research, Irvine, CA).

\section{Global Methylation}

Global DNA 5-methylcytosine (5-mC) was quantified using the 5-mC ELISA DNA kit (Zymo Research). The kit works with a unique anti-5-mC monoclonal antibody that is sensitive and specific for $5-\mathrm{mC}$ across a wide range of starting DNA amount. The 5-mC percentage was quantified based on a standard curve, generated by combining the positive $(100 \%)$ and negative $(0 \%)$ controls. A total of $100 \mathrm{ng}$ of DNA were mixed with a 5 -mC coating buffer, denatured at $98^{\circ} \mathrm{C}$ for 5 min, placed on ice immediately, and then incubated in duplicate in a 96 -well plate at $37^{\circ} \mathrm{C}$ for $1 \mathrm{~h}$. The coating buffer and samples were discarded, washed $3 \times$ with 200 $\mu \mathrm{L}$ of $5-\mathrm{mC}$ buffer, and incubated at $37^{\circ} \mathrm{C}$ for $30 \mathrm{~min}$ with 5-mC buffer. After discarding the contents, $100 \mu \mathrm{L}$ of the antibody mix containing anti-5-mC, secondary antibody, and 5-mC buffer was added and incubated at $37^{\circ} \mathrm{C}$ for $1 \mathrm{~h}$. After discarding the contents, the washing step was performed as before, with $100 \mu \mathrm{L}$ of horseradish peroxidase-developer added and incubated at room temperature for $1 \mathrm{~h}$. Absorbance at 405 and $450 \mathrm{~nm}$ was measured using a plate reader.

\section{Promoter Region-Specific DNA Methylation}

To identify a PPAR $\alpha$-specific methylation DNA region, we used the OneStep qMethyl kit (Cat\# D5310, Zymo Research), which is a real-time procedure for bisulfite-free determination of DNA methylation of specific sequences that contain $\mathrm{CpG}$ islands within a gene of interest. Nonmethylated DNA (negative control) was obtained by whole-genome amplification (GenomiPhi V3 DNA Amplification Kit; GE Healthcare, Pittsburgh, PA), and methylated control (positive) was obtained by Methylase reaction (CpG Methylase; Zymo Research). Controls and samples were purified using the Genomic DNA Clean and Concentrator Kit (Zymo Research). The 3 primers used in the present study were designed to cover 2 sections in the promoter region and one within the gene sequence of PPARA (Table 2). Primers 1 and 2 in the promoter region covered from $-1,538$ to $-1,418$ and from $-1,153$ to -911 bp relative to the transcription-starting site, respectively, whereas primer 3 covered the gene sequence from 1,450 to 1,600 bp from the transcription-starting site. The primers 1 , 2 , and 3 contained 4,12 , and $2 \mathrm{CpG}$ sites, respectively. Samples were split in 2 equal parts, one part (e.g., test reaction) digested with methylation-sensitive restriction enzymes and the other part (e.g., reference reaction) mock-digested according to the OneStep qMethyl 
Table 2. Primer region, sequence, and amplicon size of primers used to analyze peroxisome proliferator-activated receptor alpha (PPAR $\alpha)$ specific DNA methylation

\begin{tabular}{lllll}
\hline Primer & Region & Primer & Primer sequence $\left(5^{\prime}\right.$ to $\left.3^{\prime}\right)$ & Amplicon size $(\mathrm{bp})$ \\
\hline 1 & Promoter region & Forward: 1538 & GCGTCACCGCGCAAACAAAG & 120 \\
& & Reverse: 1418 & CTCTGTGCCCAGCCGAGGAG & \\
2 & Promoter region & Forward: 1153 & GCCCTGCGCTCTCCCTAGAC & 242 \\
3 & & Reverse: 911 & TACTCCGCGCGTGACTGGAC & \\
& & Forward: 1450 & AATGCAGGAGGGTATTGTGC & 150 \\
\hline
\end{tabular}

kit. The DNA from both samples was amplified using real-time PCR in the presence of a fluorescent dye and then quantified. Cycle threshold values for test and reference DNA samples vary according to methylation status, with large cycle threshold differences most characteristic of nonmethylated DNA.

\section{Statistical Analysis}

The gene expression data were analyzed with the MIXED procedure of SAS 9.3 (SAS Institute, Inc., Cary, NC). The fixed effects in the model included diet, parity, time, and their interactions. The random effect was cow. Parity and its interactions were removed from the model anytime these effects were nonsignificant $(P$ $>0.05)$. Unequally spaced data were analyzed using the exponential correlation covariance structure SP for repeated measures. As explained previously (Osorio et al., 2014a), the SM and MS products differ in the way they could provide extra Met to the cow. From a biological standpoint, however, we believe that the evaluation of the Met effect regardless of its delivery form (MS or SM) is more meaningful. Therefore, this was done via the contrast $\mathrm{MS}+\mathrm{SM}$ vs. CON at both, the main effect of diet level and at a given time point when a diet $\times$ time effect $(\mathbf{D} \times \mathbf{T} ; P \leq 0.10)$ was observed. Statistical significance was declared at $P \leq$ 0.05 , and tendencies at $P \leq 0.15$.

\section{RESULTS}

\section{Hepatic Gene Expression}

Carnitine Synthesis and Uptake. Main effects of diet, time, and their interaction for genes associated with carnitine synthesis and uptake are reported in Figure 1. A D $\times$ T interaction was noted for SLC22A5 $(P$ $<0.01)$ and TMLHE $(P<0.01)$, but not for BBOX1 $(P=0.44)$. Those responses were due to the greater expression of SLC22A5 and TMLHE in Met-supplemented cows at $7 \mathrm{~d}(P=0.05)$ and a trend at $-10 \mathrm{~d}(P$ $=0.07)$, respectively.

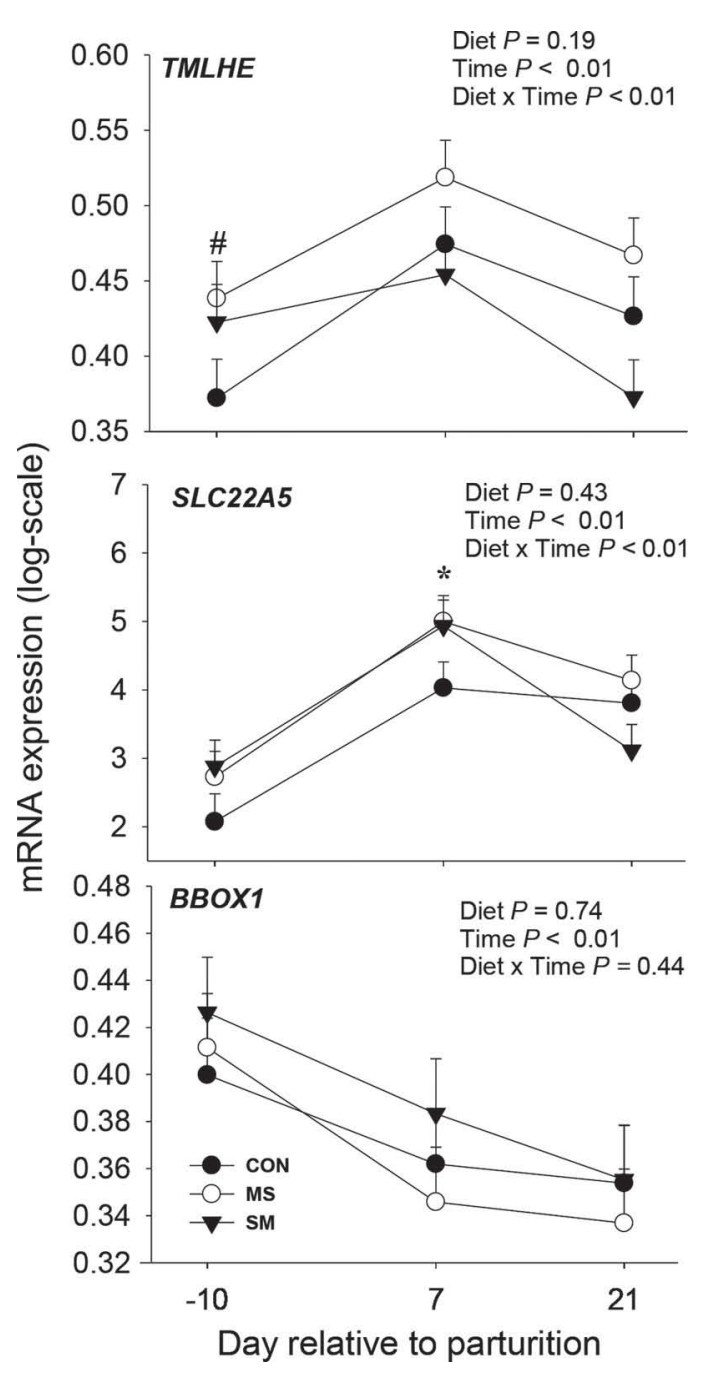

Figure 1. Expression of genes related to carnitine synthesis and uptake in cows supplemented with MetaSmart (MS; Adisseo NA, Alpharetta, GA) or Smartamine M (SM; Adisseo NA, Alpharetta, GA) at a rate of 0.19 or $0.07 \%$ of DMI throughout the peripartal period. The $P$-values for main effect of treatment (diet), time, and interaction of diet $\times$ time, as well as the contrast MS+SM vs. control (CON; when contrast $P<0.10)$, are shown. Mean separations between diets at a given time point were evaluated when a diet $\times$ time effect $(P \leq 0.10)$ was observed via contrasts $(P \leq 0.05)$ and are denoted as MS+SM vs. CON $(*)$ and tendencies $(P \leq 0.10)$ as MS+SM vs. CON $(\#)$. Values are means, with standard errors represented by vertical bars. 


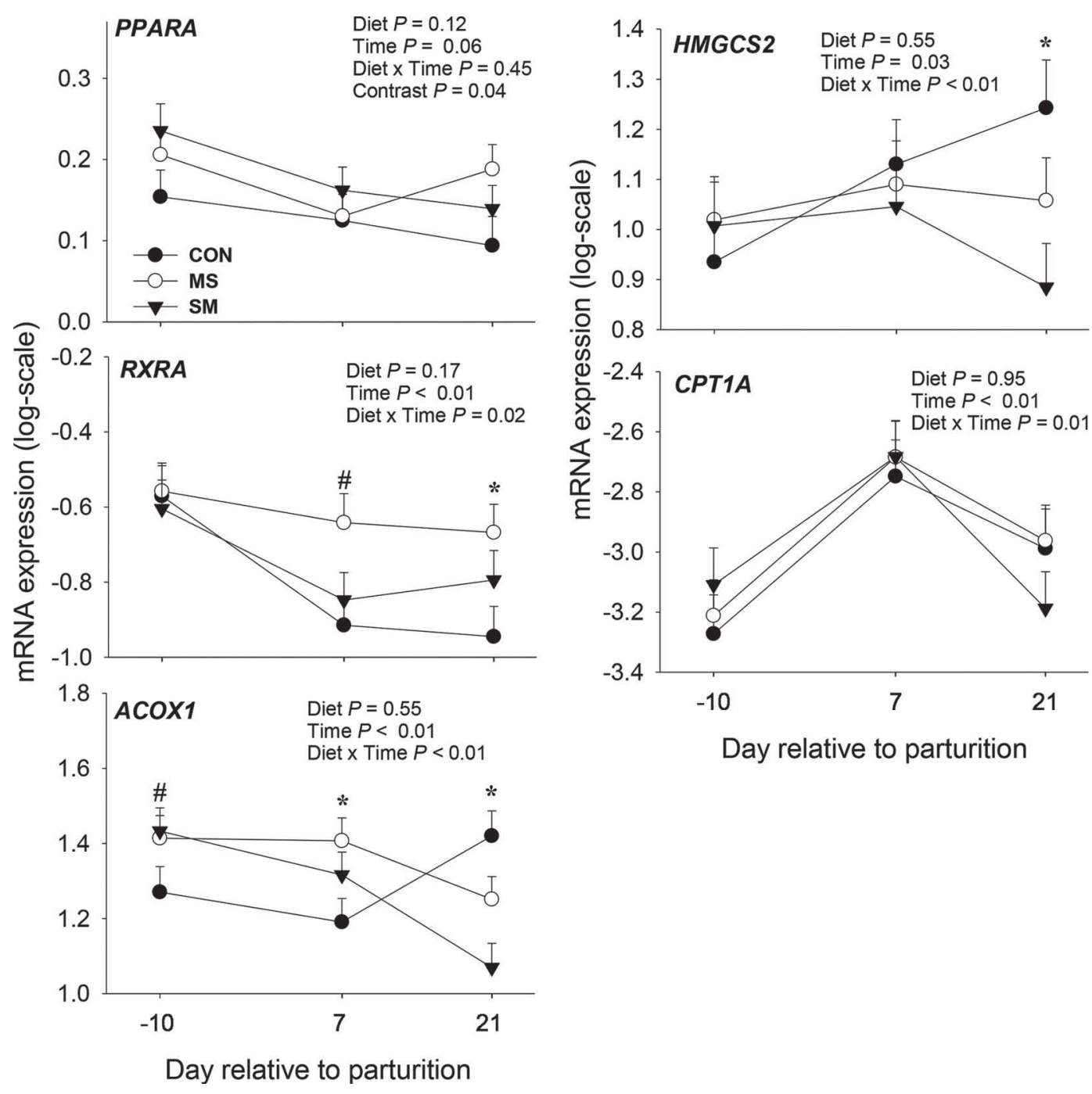

Figure 2. Expression of genes related to fatty acid metabolism in cows supplemented with MetaSmart (MS; Adisseo NA, Alpharetta, GA) or Smartamine M (SM; Adisseo NA, Alpharetta, GA) at a rate of 0.19 or $0.07 \%$ of DMI throughout the peripartal period. The $P$-values for main effect of treatment (diet), time, and interaction of diet $\times$ time, as well as the contrast MS+SM vs. control (CON; when contrast $P \leq 0.10)$, are shown. Mean separations between diets at a given time point were evaluated when a diet $\times$ time effect $(P<0.10)$ was observed via contrasts $(P$ $\leq 0.05)$ and are denoted as MS+SM vs. CON $(*)$ and tendencies $(P \leq 0.10)$ as MS+SM vs. CON (\#). Values are means, with standard errors represented by vertical bars.

\section{Fatty Acid Metabolism}

Main effects of diet, time, and their interaction for genes associated with fatty acid metabolism are reported in Figure 2. With the exception of PPARA ( $P$ $=0.45)$, a $\mathrm{D} \times \mathrm{T}(P<0.02)$ interaction was noted for all genes. Expression of $A C O X 1$ was greater in Metsupplemented cows than CON at $7 \mathrm{~d}(P=0.03)$ and tended to be greater at $-10 \mathrm{~d}(P=0.07)$; however, ACOX1 expression was lower $(P=0.003)$ in Metsupplemented cows at $21 \mathrm{~d}$ relative to parturition.

Expression of HMGCS2 at $21 \mathrm{~d}$ postpartum was similar to $A C O X 1$ with lower $(P=0.02)$ expression in
Met-supplemented cows than CON. A trend $(P=0.08)$ for greater expression of $R X R A$ was seen in Met-supplemented cows as opposed to CON at $7 \mathrm{~d}$ postpartum, followed by a similar effect of greater $(P=0.03)$ expression of $R X R A$ in Met-supplemented cows than CON at 21 d. Expression of PPARA was greater $(P=0.04)$ in Met-supplemented cows than CON and decreased $(P<$ $0.05)$ over time regardless of treatment. The significant $(P=0.01) \mathrm{D} \times \mathrm{T}$ interaction for $C P T 1 A$ did not translate into differences between diets at any time point.

Hepatokines. Main effects of diet, time, and their interaction for hepatokines are reported in Figure 3. The $\mathrm{D} \times \mathrm{T}$ interaction was significant $(P<0.01)$ for 


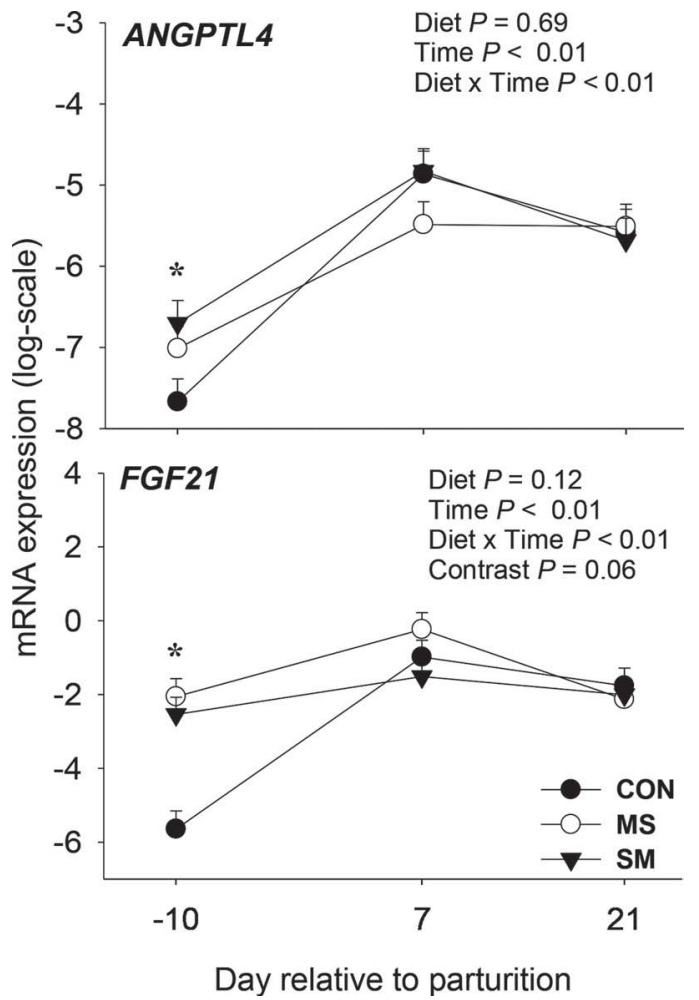

Figure 3. Expression of hepatokines (FGF21 and ANGPTL4) in cows supplemented with MetaSmart (MS; Adisseo NA, Alpharetta, GA) or Smartamine M (SM; Adisseo NA, Alpharetta, GA) at a rate of 0.19 or $0.07 \%$ of DMI throughout the peripartal period. The $P$-values for main effect of treatment (diet), time, and interaction of diet $\times$ time, as well as the contrast MS+SM vs. control (CON; when contrast $P \leq 0.10)$ are shown. Mean separations between diets at a given time point were evaluated when a diet $\times$ time effect $(P \leq 0.10)$ was observed via contrasts $(P \leq 0.05)$ and are denoted as MS+SM vs. CON $(*)$. Values are means, with standard errors represented by vertical bars.

FGF21 and ANGPTL4. Expression of FGF21 $(P<$ $0.001)$ and $A N G P T L 4(P=0.03)$ was greater in Metsupplemented cows than $\mathrm{CON}$ at $-10 \mathrm{~d}$, and that effect for FGF21 translated into a trend for overall greater $(P$ $=0.06$ ) expression in Met-supplemented cows.

Gluconeogenesis and VLDL Synthesis and Export. Main effects of diet, time, and their interaction for genes associated with gluconeogenesis, and VLDL synthesis and export are reported in Figure 4. The D $\times \mathrm{T}$ interaction was significant $(P<0.05)$ for all genes with the exception $(P=0.12)$ of $P D K 4$. Expression of $P C(P=0.05)$ and $M T T P(P<0.001)$ at $21 \mathrm{~d}$ postpartum was lower in Met-supplemented cows than CON. Overall expression of $P C K 1$ was greater $(P=$ $0.03)$ in Met-supplemented cows than CON, primarily due to greater expression at $7 \mathrm{~d}(P=0.005)$ and 21 $\mathrm{d}(P=0.04)$. Overall expression of $P D K 4$ increased $(P<0.001)$ over time regardless of treatment and, even though the $\mathrm{D} \times \mathrm{T}$ effect did not reach statisti- cal significance $(P=0.12)$, both $\mathrm{MS}$ and $\mathrm{SM}$ had an upregulation $(P<0.001)$ of $P D K 4$ from -10 to $21 \mathrm{~d}$. In CON cows, $P D K 4$ expression remained unchanged $(P$ $=0.30)$. Expression of $A P O B$ was greater $(P=0.04)$ in $\mathrm{SM}$ cows than $\mathrm{CON}$ at $-10 \mathrm{~d}$, whereas expression in Met-supplemented cows was lower $(P=0.05)$ than $\mathrm{CON}$ at $21 \mathrm{~d}$ postpartum.

\section{Global and DNA Region Specific-PPARA Methylation}

Main effects of diet for global and region-specific PPARA DNA methylation at $21 \mathrm{~d}$ are reported in Figure 5. Global DNA methylation was affected by diet $(P=0.03)$, which was reflected in lower $(P=0.06)$ global DNA methylation in Met-supplemented cows than CON. Although region-specific PPARA methylation was only affected by $\operatorname{diet}(P=0.01)$ with primer 1 , for all primer sets evaluated at least a trend $(P<$ 0.14 ) was observed for greater DNA region-specific PPARA methylation in Met-supplemented cows than CON (Figure 5).

\section{DISCUSSION}

In previous publications we reported data demonstrating a benefit of supplemental rumen-protected Met during the peripartal period (Osorio et al., 2013). Such data suggested a potential deficiency in the amount of Met reaching the small intestine in diets with a Lysto-Met ratio $>2.9: 1$. Supplemental Met enhanced liver function with a concomitant decrease in the inflammatory status, all of which resulted in greater voluntary DMI and milk production (Osorio et al., 2013, 2014b).

By overriding the predetermined genetic information in the DNA, and consequently the phenotype in mammals, the methylation of DNA can induce profound modifications of the transcriptome profile. Although the importance of DNA methylation in the context of epigenetics has been underscored in nonruminants (Burdge and Lillycrop, 2010; Singh et al., 2012), the mechanisms governing global and region-specific DNA methylation are poorly understood, specifically in the context of nutriepigenomics.

Dietary methyl donors (e.g., choline, betaine, Met) are the major drivers of DNA methylation because they are essential for synthesis of SAM. The expression of specific genes (e.g., PPARA) might be silenced or repressed depending on global DNA-hyper or DNA-hypomethylation (Wang et al., 2013, 2014). For instance, mice fed a betaine-enriched diet had hypermethylation of hepatic DNA while the PPARA promoter region was hypomethylated, consequently upregulating expression of PPARA (Wang et al., 2013). Within the context of peripartal dairy cow nutrition the latter effect has not 
been evaluated and represents a novel mechanism by which dietary methyl donors could exert beneficial effects at a metabolic level.

\section{PPARA and Fatty Acid Metabolism}

The upregulation of PPARA via Met supplementation and the greater postpartal expression of $R X R A$ underscores the potential for greater activity of the heterodimer (Bionaz et al., 2013) formed by PPAR $\alpha-$ retinoid $\mathrm{X}$ receptor- $\alpha$ during this physiological stage. The decrease in overall expression of PPARA from -10 to 7 and $21 \mathrm{~d}$ postpartum contrasts with previous studies
(Loor et al., 2005; Schlegel et al., 2012) where PPARA upregulation occurred as early as 1 wk after calving, even when rumen-protected choline was supplemented (Goselink et al., 2013); however, not all studies have reported upregulation of PPARA after calving (Carriquiry et al., 2009; Weber et al., 2013).

In the context of DNA methylation, it seems plausible that supplemental rumen-protected Met through SAM served to enhance DNA methylation leading to greater PPARA upregulation postcalving. The specific mechanism for such effect remains to be fully elucidated. In murine hepatocytes, global DNA hypomethylation occurs in spite of specific gene promoters being

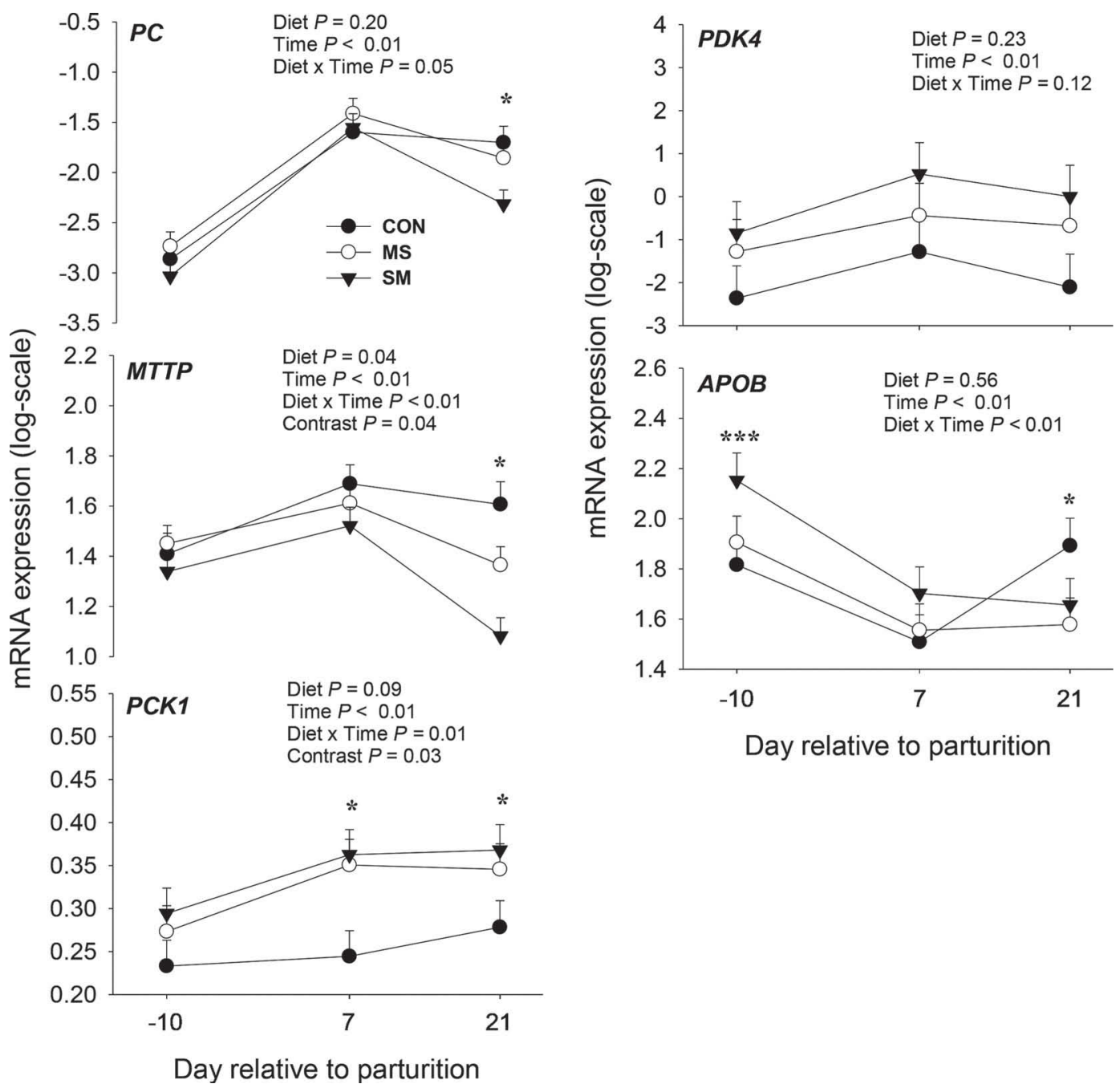

Figure 4. Expression of genes related to gluconeogenesis ( $P D K 4, P C K 1$, and $P C$ ), and very low-density lipoprotein synthesis or export $(M T T P$ and $A P O B)$ in cows supplemented with MetaSmart (MS; Adisseo NA, Alpharetta, GA) or Smartamine M (SM; Adisseo NA, Alpharetta, GA) at a rate of 0.19 or $0.07 \%$ of DMI throughout the peripartal period. The $P$-values for main effect of treatment (diet), time, and interaction of diet $\times$ time, as well as the contrast MS+SM vs. control $(\mathrm{CON}$; when contrast $P \leq 0.10)$ are shown. Mean separations between diets at a given time point were evaluated when a diet $\times$ time effect $(P \leq 0.10)$ was observed via contrasts $(P \leq 0.05)$ and are denoted as MS+SM vs. CON $(*)$ and SM vs. CON $(* * *)$. Values are means, with standard errors represented by vertical bars. 
hypermethylated, with the overall effect being downregulation or attenuation of the expression of the gene (Wang et al., 2013).

In nonruminants, methyl-deficient diets have been associated with hypermethylation of specific gene promoters (Tryndyak et al., 2011). As mentioned previously, a study using betaine as a dietary methyl donor to reduce hypermethylation in male rats led to the finding that it upregulated PPARA as a result of hypomethylation of its promoter (Wang et al., 2013). Our results of a lower global DNA methylation and hypermethylation of a PPARA specific-DNA region in both the promoter and gene sequence contrast those of Wang et al. (2013). It should be kept in mind that the PPARA sequence used to identify the methylationspecific region was substantially different (7216 bp GenBank: NM_001113418.1 compared with 1979 bp GenBank: NM_001034036.1) from that of Wang et al. (2013). In that context, an in silico analysis (Bionaz et al., 2012) of the AA sequence homology of PPAR $\alpha$ between bovine, mice, and humans revealed an overall 90\% conservation of this PPAR isotype among the 3 species; however, there was a lower ( $81 \%$ similarity) conservation between cows and mice in 1 (e.g., A/B domain) of the 4 domains of the PPAR $\alpha$ protein. The latter suggests that DNA sequence variations within specific regions between species are partly responsible for the different outcomes in both global and region-

\section{$\mathbf{A}$}
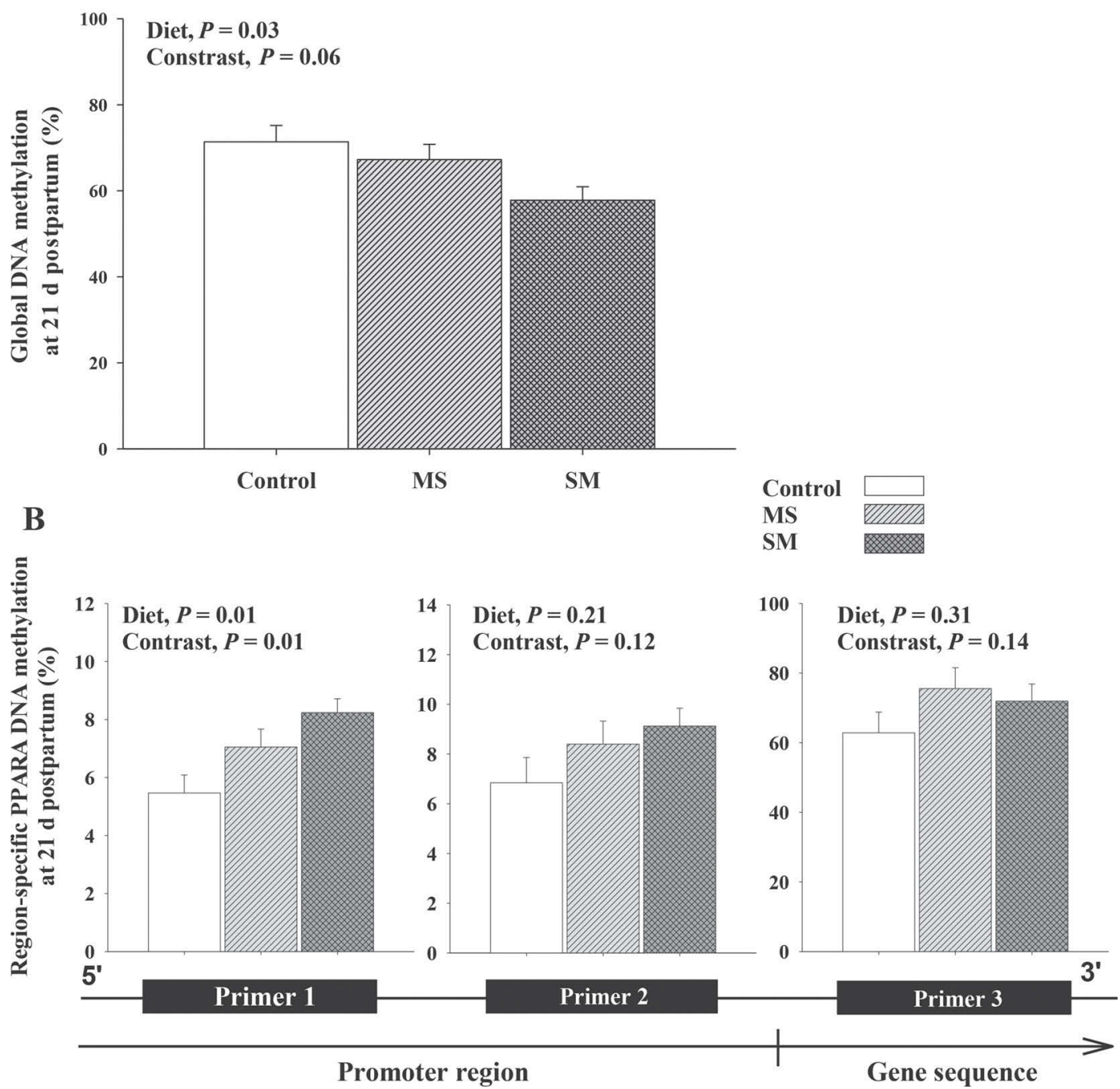

Figure 5. Effects of supplemental MetaSmart (MS; Adisseo NA, Alpharetta, GA) or Smartamine M (SM; Adisseo NA, Alpharetta, GA) at a rate of 0.19 or $0.07 \%$ of DMI throughout the peripartal period on (A) hepatic global DNA methylation and (B) hepatic promoter region-specific DNA methylation of PPARA at $21 \mathrm{~d}$ postpartum for the 3 primer sets evaluated in the promoter region and gene sequence. Contrast $=$ control $(\mathrm{CON})$ versus $\mathrm{MS}+\mathrm{SM}$. 
specific DNA methylation in response to dietary methyl donors. The onset of lactation also could have played a role because this period is associated with a significant demand (Preynat et al., 2009) for methyl donors (i.e., Met, choline) in contrast to the male rats used in Wang et al. (2013).

Another reason for the lower global methylation in Met-supplemented cows could be the downregulation in expression of DNA methyl transferase 1 (DNMT1; Osorio et al., 2014a), an enzyme in charge of the maintenance of methylated $\mathrm{CpG}$ islands. Although our results are not completely in line with those observed in rodents fed methyl-deficient diets (e.g., global methylation and region-specific methylation), the data underscore a biological effect of Met supplementation on global DNA methylation and region-specific PPARA methylation. The latter likely contributes to an upregulation of PPARA expression. Such an effect constitutes a novel mechanism whereby methyl donors, such as betaine, choline, or Met, as sources of SAM could elicit biological effects beyond the well-established lipotropic effect.

Genes involved in carnitine biosynthesis (TMLHE and $B B O X 1)$ and uptake of carnitine from blood $(S L$ C22A5) are known target genes of PPAR (Schlegel et al., 2012). Among these, the upregulation of TMLHE and SLC22A5 at -10 and $7 \mathrm{~d}$, respectively, via Met supplementation could be partly explained by the upregulation of PPARA (Figure 2). The upregulation of TMLHE in Met-supplemented cows at $-10 \mathrm{~d}$ coupled with overall greater prepartal expression of $B B O X 1$ suggests these cows had greater rates of carnitine synthesis in the liver before calving. Previously, Carlson et al. (2007) and Schlegel et al. (2012) reported that the concentrations of free carnitine in plasma strongly decrease between 3 wk prepartum and 1 wk postpartum. Such a response suggests that Met-supplemented cows benefitted from increased transport of carnitine from plasma into liver due to greater SLC22A5.

The greater expression of $A C O X 1$ in Met-supplemented cows at -10 and $7 \mathrm{~d}$ relative to parturition is in agreement with the previous association of this gene as a target for PPAR $\alpha$ (Loor, 2010). However, the downregulation of $H M G C S 2$ by Met-supplementation at $21 \mathrm{~d}$ suggests that other mechanisms might have overridden the PPARA activation observed in Met-supplemented cows. Among these mechanisms, it could be argued that greater hepatic lipid accumulation in CON cows at $21 \mathrm{~d}$ postpartum (Osorio et al., 2013) triggered the greater response of HMGCS2, consequently predisposing them to develop ketosis. Such an effect also could account for the lower expression of ACOX1 at $21 \mathrm{~d}$ in Met-supplemented cows.

\section{Hepatokines, Gluconeogenesis, and VLDL Synthesis and Export}

Fibroblast growth factor-21 is a potent regulator of metabolism in nonruminants that upon activation can stimulate hepatic gluconeogenesis, glucose uptake in adipocytes, fatty acid oxidation, and ketogenesis (Schoenberg et al., 2011). Consistent with previous research (Khan et al., 2014), overall expression of FGF21 increased after calving. This gene is a well-known PPAR $\alpha$ target in nonruminants (Loor, 2010), and the greater expression of FGF21 in Met-supplemented cows suggests bovine PPAR $\alpha$ also controls its expression. The upregulation of FGF21 via PPAR $\alpha$ activation, but not of $C P T 1 A$, is in agreement with results observed by Akbar et al. (2013) in feed-restricted cows. Similar to FGF21, ANGPTL4 is considered a PPAR $\alpha$ target and its greater prepartal expression in Met-supplemented cows supports an activation via PPAR. Upon activation, ANGPTL4 inhibits LPL activity in adipose tissue, enhances lipolysis, and its expression is upregulated during undernutrition and negative energy balance soon after calving (Loor et al., 2007).

The proteins encoded by $A P O B$ and $M T T P$ are closely related to hepatic secretion of VLDL. The gene $A P O B$ encodes an apolipoprotein that is an essential component of VLDL; whereas microsomal triglyceride transfer protein is crucial for the assembly of phospholipids, cholesterol ester, and TAG into VLDL (Loor, 2010). The greater prepartal expression of $A P O B$ coupled with its greater mRNA abundance among all genes evaluated (Table 1) in Met-supplemented cows could have primed cells for greater translation into APOB, which is consistent with the greater serum concentration of this apolipoprotein in the Met-supplemented cows (Osorio et al., 2013). Taken together, it appears lower postpartal $(21 \mathrm{~d})$ demand for transcriptional adjustments toward hepatic VLDL secretion occurred in Met-supplemented cows, in part because of the low circulating concentrations of fatty acids (Osorio et al., 2013).

The upregulation of $P C K 1$ and to a lesser extent $P D K_{4}$ in Met-supplemented cows suggests that gluconeogenesis was enhanced. This offers support for the role of the PPARA-FGF21 axis as a promoter of gluconeogenesis (Fisher et al., 2011). Targeting of PDK4 via activation of the PPARA-FGF21 axis was observed in fasted male rats (Palou et al., 2008), and PCK1 increased along with FGF21 expression in feed-restricted dairy cows (Akbar et al., 2013). Despite these changes in gene expression, no difference in plasma glucose concentration was noted in Met-supplemented cows compared with controls (Osorio et al., 2013). Because 
of the highly regulated nature of blood glucose, it is likely that other factors such as mammary gland glucose uptake for lactose synthesis might have controlled glucose concentration in Met-supplemented cows.

The enzyme encoded by $P C$, pyruvate carboxylase, promotes the conversion of pyruvate to oxaloacetate, thus allowing lactate and some AA, such as Ala, to be converted into pyruvate. Oxaloacetate can be further used as a substrate for gluconeogenesis in the cytosol. Both, propionate supplied by rumen fermentation and Met from the diet and body reserves can enter the Krebs cycle at the level of succinyl-CoA (Champe et al., 2008). The fact that succinyl-CoA can be converted into oxaloacetate downstream from the Krebs cycle diminishes the requirement of PC and Ala for gluconeogenesis, especially during positive energy balance (Bell et al., 2000). Therefore, the lower expression of $P C$ at $21 \mathrm{~d}$ in Met-supplemented cows could be taken as a sign of lower dependence of these cows on Ala and other AA.

\section{CONCLUSIONS}

Although it is possible that mechanisms whereby methyl donors activate PPARA through DNA methylation differ between monogastrics and ruminants, we observed similar overall effects on the target genes studied. As originally hypothesized, Met via synthesis of SAM activated PPARA and several of its target genes, including hepatokines and gluconeogenesis-related genes. Upregulation of hepatic PPARA has been associated with improved lipid metabolism and immune function, both of which were reported in companion publications from this study. In turn, those positive effects resulted in improved postpartal health and performance. To our knowledge, this is the first study where a dietary methyl donor such as Met was associated with PPARA upregulation. Further research is needed to study more closely the mechanistic connections between global DNA and region-specific PPARA methylation with $P P A R A$ expression and functional outcomes in liver.

\section{ACKNOWLEDGMENTS}

The authors gratefully acknowledge Adisseo NA (Commentry, France) and National Institute of Food and Agriculture (Washington, DC; Hatch funds under project ILLU-538-914) for partial financial support of this research. The authors thank Travis Michels and Mike Katterhenry of the University of Illinois Dairy Research Unit (Urbana) staff for help with animal management. Carolina Jacometo was supported in part by a fellowship from Coordenação de Aperfeiçoamento de Pessoal de Nível Superior (CAPES, Brasilia, DF, Brazil) from the Brazilian Ministry of Education.

\section{REFERENCES}

Akbar, H., E. Schmitt, M. A. Ballou, M. N. Correa, E. J. Depeters, and J. J. Loor. 2013. Dietary lipid during late-pregnancy and early-lactation to manipulate metabolic and inflammatory gene network expression in dairy cattle liver with a focus on PPARs. Gene Regul. Syst. Bio. 7:103-123.

Bauchart, D., D. Durand, D. Gruffat, and Y. Chilliard. 1998. Mechanism of liver steatosis in early lactation cows: Effects of hepatoprotector agents. Pages 27-37 in Proc. Cornell Nutr. Conf. Feed Manuf. Cornell University, Ithaca, NY.

Bell, A. W., W. S. Burhans, and T. R. Overton. 2000. Protein nutrition in late pregnancy, maternal protein reserves and lactation performance in dairy cows. Proc. Nutr. Soc. 59:119-126.

Bionaz, M., S. Chen, M. J. Khan, and J. J. Loor. 2013. Functional role of PPARs in ruminants: Potential targets for fine-tuning metabolism during growth and lactation. PPAR Res. 2013:684159.

Bionaz, M., and J. J. Loor. 2008. Gene networks driving bovine milk fat synthesis during the lactation cycle. BMC Genomics 9:366.

Bionaz, M., B. J. Thering, and J. J. Loor. 2012. Fine metabolic regulation in ruminants via nutrient-gene interactions: Saturated longchain fatty acids increase expression of genes involved in lipid metabolism and immune response partly through PPAR-alpha activation. Br. J. Nutr. 107:179-191.

Burdge, G. C., and K. A. Lillycrop. 2010. Nutrition, epigenetics, and developmental plasticity: Implications for understanding human disease. Annu. Rev. Nutr. 30:315-339.

Carlson, D. B., J. W. McFadden, A. D'Angelo, J. C. Woodworth, and J. K. Drackley. 2007. Dietary L-carnitine affects periparturient nutrient metabolism and lactation in multiparous cows. J. Dairy Sci. 90:3422-3441.

Carriquiry, M., C. R. Dahlen, W. J. Weber, G. C. Lamb, and B. A. Crooker. 2009. Postpartum ovarian activity in multiparous Holstein cows treated with bovine somatotropin and fed n-3 fatty acids in early lactation. J. Dairy Sci. 92:4876-4888.

Champe, P. C., R. A. Harvey, and D. R. Ferrier. 2008. Biochemistry. 4th ed. Lippincott's Illustrated Reviews. Wolters Kluwer Health/ Lippincott Williams \& Wilkins, Philadelphia, PA.

Fisher, F. M., J. L. Estall, A. C. Adams, P. J. Antonellis, H. A. Bina, J. S. Flier, A. Kharitonenkov, B. M. Spiegelman, and E. Maratos-Flier. 2011. Integrated regulation of hepatic metabolism by fibroblast growth factor 21 (FGF21) in vivo. Endocrinology 152:2996-3004.

Goselink, R. M., J. van Baal, H. C. Widjaja, R. A. Dekker, R. L. Zom, M. J. de Veth, and A. M. van Vuuren. 2013. Effect of rumenprotected choline supplementation on liver and adipose gene expression during the transition period in dairy cattle. J. Dairy Sci. 96:1102-1116.

Khan, M. J., C. B. Jacometo, D. E. Graugnard, M. N. Corrêa, E. Schmitt, F. Cardoso, and J. J. Loor. 2014. Overfeeding dairy cattle during late-pregnancy alters hepatic PPAR $\alpha$-regulated pathways including hepatokines: Impact on metabolism and peripheral insulin sensitivity. Gene Regul. Syst. Bio. 8:97-111.

Loor, J. J. 2010. Genomics of metabolic adaptations in the peripartal cow. Animal 4:1110-1139.

Loor, J. J., H. M. Dann, R. E. Everts, R. Oliveira, C. A. Green, N. A. Guretzky, S. L. Rodriguez-Zas, H. A. Lewin, and J. K. Drackley. 2005. Temporal gene expression profiling of liver from periparturient dairy cows reveals complex adaptive mechanisms in hepatic function. Physiol. Genomics 23:217-226.

Loor, J. J., R. E. Everts, M. Bionaz, H. M. Dann, D. E. Morin, R. Oliveira, S. L. Rodriguez-Zas, J. K. Drackley, and H. A. Lewin. 2007. Nutrition-induced ketosis alters metabolic and signaling gene networks in liver of periparturient dairy cows. Physiol. Genomics 32:105-116.

Lu, S. C., and J. M. Mato. 2012. S-adenosylmethionine in liver health, injury, and cancer. Physiol. Rev. 92:1515-1542. 
Martinov, M. V., V. M. Vitvitsky, R. Banerjee, and F. I. Ataullakhanov. 2010. The logic of the hepatic methionine metabolic cycle. Biochim. Biophys. Acta 1804:89-96.

NRC. 2001. Nutrient Requirements of Dairy Cattle. Vol. 7th. Natl. Acad. Press, Washington, DC.

Ordway, R. S., S. E. Boucher, N. L. Whitehouse, C. G. Schwab, and B. K. Sloan. 2009. Effects of providing two forms of supplemental methionine to periparturient Holstein dairy cows on feed intake and lactational performance. J. Dairy Sci. 92:5154-5166.

Osorio, J. S., P. Ji, J. K. Drackley, D. Luchini, and J. J. Loor. 2013. Supplemental Smartamine M or MetaSmart during the transition period benefits postpartal cow performance and blood neutrophil function. J. Dairy Sci. 96:6248-6263.

Osorio, J. S., P. Ji, J. K. Drackley, D. Luchini, and J. J. Loor. 2014a. Smartamine M and MetaSmart supplementation during the peripartal period alter hepatic expression of gene networks in 1-carbon metabolism, inflammation, oxidative stress, and the growth hormone-insulin-like growth factor 1 axis pathways. J. Dairy Sci. 97:7451-7464.

Osorio, J. S., E. Trevisi, P. Ji, J. K. Drackley, D. Luchini, G. Bertoni, and J. J. Loor. 2014b. Biomarkers of inflammation, metabolism, and oxidative stress in blood, liver, and milk reveal a better immunometabolic status in peripartal cows supplemented with Smartamine M or MetaSmart. J. Dairy Sci. 97:7437-7450.

Palou, M., T. Priego, J. Sanchez, E. Villegas, A. M. Rodriguez, A. Palou, and C. Pico. 2008. Sequential changes in the expression of genes involved in lipid metabolism in adipose tissue and liver in response to fasting. Pflugers Arch. 456:825-836.

Preynat, A., H. Lapierre, M. C. Thivierge, M. F. Palin, J. J. Matte, A. Desrochers, and C. L. Girard. 2009. Effects of supplements of folic acid, vitamin B12, and rumen-protected methionine on whole body metabolism of methionine and glucose in lactating dairy cows. J. Dairy Sci. 92:677-689.

Schlegel, G., J. Keller, F. Hirche, S. Geissler, F. J. Schwarz, R. Ringseis, G. I. Stangl, and K. Eder. 2012. Expression of genes involved in hepatic carnitine synthesis and uptake in dairy cows in the transition period and at different stages of lactation. BMC Vet. Res. 8:28.

Schoenberg, K. M., S. L. Giesy, K. J. Harvatine, M. R. Waldron, C. Cheng, A. Kharitonenkov, and Y. R. Boisclair. 2011. Plasma FGF21 is elevated by the intense lipid mobilization of lactation. Endocrinology 152:4652-4661.

Singh, K., A. J. Molenaar, K. M. Swanson, B. Gudex, J. A. Arias, R. A. Erdman, and K. Stelwagen. 2012. Epigenetics: A possible role in acute and transgenerational regulation of dairy cow milk production. Animal 6:375-381.

Tryndyak, V. P., T. Han, L. Muskhelishvili, J. C. Fuscoe, S. A. Ross, F. A. Beland, and I. P. Pogribny. 2011. Coupling global methylation and gene expression profiles reveal key pathophysiological events in liver injury induced by a methyl-deficient diet. Mol Nutr. Food Res. 55:411-418.

Wang, L., L. Chen, Y. Tan, J. Wei, Y. Chang, T. Jin, and H. Zhu. 2013. Betaine supplement alleviates hepatic triglyceride accumulation of apolipoprotein $\mathrm{E}$ deficient mice via reducing methylation of peroxisomal proliferator-activated receptor alpha promoter. Lipids Health Dis. 12:34.

Wang, L. J., H. W. Zhang, J. Y. Zhou, Y. Liu, Y. Yang, X. L. Chen, C. H. Zhu, R. D. Zheng, W. H. Ling, and H. L. Zhu. 2014. Betaine attenuates hepatic steatosis by reducing methylation of the MTTP promoter and elevating genomic methylation in mice fed a high-fat diet. J. Nutr. Biochem. 25:329-336.

Weber, C., C. Hametner, A. Tuchscherer, B. Losand, E. Kanitz, W. Otten, H. Sauerwein, R. M. Bruckmaier, F. Becker, W. Kanitz, and H. M. Hammon. 2013. Hepatic gene expression involved in glucose and lipid metabolism in transition cows: Effects of fat mobilization during early lactation in relation to milk performance and metabolic changes. J. Dairy Sci. 96:5670-5681. 